\title{
ETHNOGRAPHIC FILM-MAKING IN AUSTRALIA THE FIRST SEVENTY YEARS (1898-1968)
}

\author{
Ian Dunlop
}

Ethnographic film-making is almost as old as cinema itself. ${ }^{1}$ In 1877 Edison, in America, perfected his phonograph, the world's first machine for recording sound on fragile wax cylinders. He then started experimenting with ways of producing moving pictures. Others in England and France were also experimenting at the same time. Amongst these were the Lumière brothers of Paris. In 1895 they perfected a projection machine and gave the world's first public screening. The cinema was born The same year Felix-Louis Renault filmed a Wolof woman from west Africa making pots at the Exposition E thnographique de l'Afrique Occidentale in Paris. ${ }^{2}$ Three years later ethnographic film was being shot in the Torres Strait Islands just north of mainland Australia.

This was in 1898 when Alfred Cort Haddon, an English zoologist and anthropologist, mounted his Cambridge Anthropological Expedition to the Torres Strait. His recording equipment included a wax cylinder sound recorder and a Lumière camera. The technical genius of the expedition, and the man who apparently used the camera, was Anthony Wilkin. ${ }^{3}$ It is not known how much film he shot; unfortunately only about four minutes of it still exists. It is the first known ethnographic film to be shot in the field anywhere in the world. It is of course black and white, shot on one of the world's first cameras, with a handle you had to turn to make the film go rather shakily around. The fragment we have shows several rather posed shots of men dancing and another of men attempting to make fire by friction. Haddon's wax cylinder recordings, or those that survived, were deposited with the British Institute of Recorded Sound, London, in 1955 but it seems no work has been done on them. ${ }^{4}$

The first major existing contribution to ethnographic film-making in Australia is that of Sir Walter Baldwin Spencer. As a young man of only twenty-six Baldwin Spencer came to Australia in 1887 to take up the position of foundation Professor of Biology at Melbourne University. A few years later he made his first scientific expedition into Central Australia. In Alice Springs, which was then a tiny telegraph station, he met Frank Gillen, who was in charge of the station. Gillen had a deep interest in, and respect for, the Aranda Aborigines around Alice Springs. As a result of this meeting, Spencer and Gillen became firm friends and commenced a joint study of the Aborigines which lasted for many years. Together they went deep into Aranda country, participating in the sacred life that is normally kept strictly from outsiders.

In 1900 Haddon, now back from the Torres Strait, wrote from Dublin to Baldwin Spencer in Melbourne. After congratulating him on the anthropological work he was doing, Haddon went on:

1 This paper is not a definitive account of ethnographic film-making in Australia; my aim is to give a broad general survey only. It is based upon a talk which I gave to the Australian Institute of Aboriginal Studies Ethnographic Film Conference, Canberra, May 1978. That talk was liberally illustrated with excerpts from the work of the film-makers I discussed. A draft of this present paper was circulated at the Symposium on Visual Anthropology of the Xth International Congress of Anthropological and Ethnological Sciences, Delhi, December 1978.

2 De Brigard 1975:15.

3 Personal communications, Dr G.E. Kearney, Department of Psychology, University of Queensland, and Mr Peter Gathercole, Curator, University Museum of Archaeology and Ethnology, Cambridge.

4 Personal communication, Peter Gathercole. 


\section{ABORIGINAL HISTORY 1979 3:2}

You really must take a Kinematograph or a biograph or whatever they call it in your part of the world. It is an indispensable piece of anthropological apparatus ... I have no doubt your films will pay for the whole apparatus if you care to let some of them be copied by the trade... I hope you will take a phonograph ... You will have difficulty in getting your natives to sing loud enough. ${ }^{5}$

Baldwin Spencer took Haddon's advice and in 1901, on his fifth trip to Central Australia, he took amongst his bulky equipment a large Edison phonograph and a Warwick Cinematograph which together were regarded as 'magnificent equipment' 6 as well they might be - cinema was still only six years old, still in its infancy. To go filming in the heat and dust of Central Australia today with all our modern lightweight equipment is still something of a technical nightmare. In Baldwin Spencer's day it must have been infinitely worse, travelling by horse and buggy or camel with such cumbersome and delicate equipment.

On his trip in 1901 Baldwin Spencer used his Edison phonograph (his wax cylinder recorder), for the first time a few days before he tried out the cinematograph. On 22 March 1901 he wrote in his diary, "The phonograph is a beauty'. ${ }^{7}$ Several of his original fragile wax cylinder recordings still exist and have been successfully transferred on to tape. ${ }^{8}$ I am still filled with wonder when I hear Baldwin Spencer's voice announce,'A corroborree song of the Aranda tribe recorded at Charlotte Waters, 3 April 1901 ', followed by the singing of a solo male voice.

On 4 April 1901 he tried out his movie camera for the first time. He recounts the event in his book Wanderings in wild Australia:

There was a native camp out in the scrub . . containing some thirty or forty men and women who had come in to perform a rain ceremony ... This rain dance gave us the opportunity of experimenting with the cinematograph. It was a Warwick machine, and, if not actually the first, was amongst the earliest cinematographs to be used in Australia. It was certainly the first used amongst the Aboriginals. A diagram showed how to fix the film in the machine, so as to make it run round, but no instructions had been sent out as to what rate to turn the handle, so I had to make a guess at this. The focussing glass was, of necessity, small and you could only get a sideways and not a direct view of it, but after a little practice with a blank spool, I felt equal to the first attempt in real life ... We had no idea what the Rain Ceremony was going to be like, so that all I could do was stand the machine on one side of the ceremonial ground, focus for about the centre of it and hope for the best. The lens allowed for a fair depth of focus, but the field of action covered by the natives was large and I had not, as in more recent machines, a handle to turn making it possible to follow up the actors if they moved about very much from side to side ... When the performers came on to the ground I was ready for them, and started grinding away as steadily as I could at the handle, though at first the temptation was great to vary the rate of turning to suit the rapid or slow movements of the performers .. The chief difficulty was that the performers every now and then ran off the ground into the surrounding scrub, returning at uncertain intervals of time, so that now and again, in the expectation of their suddenly reappearing, and fearful of missing anything of importance, I ground on and on, securing a record of a good deal of monotonous scenery but very little ceremony. ${ }^{9}$

5 Haddon 1900 MS.

${ }^{6}$ Moyle 1959:8.

${ }^{7}$ Moyle 1959:9.

8 For full account of Baldwin Spencer's recordings see Moyle 1959.

9 Spencer 1928:I, 359-360; further details of the actual filming may be found in Gillen's diary ontries (Gillen 1968). 
Today we have preserved some 7,000 feet of $35 \mathrm{~mm}$ film shot by Baldwin Spencer on two trips: the first in 1901 in the desert country of Central Australia and the second in 1912 in tropical Northern Australia. Considering the conditions under which the material was shot and the fact that it was not transferred from the original nitrate negative until 1966 , it is remarkably well preserved. The original negative appears not to have been edited. 10

Spencer donated his film to the National Museum of Victoria in 1916 and there it remaine $d$ in the museum vaults for over forty years. To the museum it was of course a treasure but also, as time passed, an embarrassment for they knew they were sitting on a potential incendiary bomb of unstable decaying nitrate film. Mercifully the museum staff declined to take the advice of the Chief Fire Officer of Melbourne to have it destroyed. I came across the film in 1966 when the director of the museum took me to a shed out the back. Here, for safety, were stored two tin trunks and in them, to my utter surprise, were Baldwin Spencer's original rolls of nitrate negative, still in their original cardboard boxes. With the agreement of the museum trustees the Commonwealth Film Unit (as F ilm Australia was then called) took over this material and supervised the making of a safety duplicate master from as much of it as possible. Some had disintegrated into jelly and some was just too badly shrunk to print but most of it was saved. Duplicate negatives now reside with the National Museum of Victoria, the National Library of Australia, and Film Australia,

The 1901 material covers sequences from thirteen different Aranda ceremonies. Baldwin Spencer described the material as 'the first attempt made to secure cinematograph records of native ceremonies: some of the negatives were quite good, others indifferent:" In fact some ceremonies were extremely well photographed, with individual shots of long duration in the best traditions of observational cinema. They appear mainly to be unposed and capture well the intensity of the individual performers. ${ }^{12}$

The 1912 material was shot in the northern part of the Northern Territory around Oenpelli, Flora River, and on Bathurst Island. Again it mainly covers ceremonial activities. Baldwin Spencer now had a panning head on his tripod so he could follow his subjects as they moved about. On Bathurst Island he filmed his longest sequence, of part of a Pukamuni ceremony (the Tiwi mortuary rites in which carved posts are erected around the grave of a dead person). It is interesting to compare this footage with very recent films of the same ceremony. ${ }^{13}$

On the 1912 expedition Baldwin Spencer also tried to film some domestic scenes but without much success. He explains why:

I spent some time trying to get cinematograph pictures of camp life. It would be quite easy to do this with a small hand machine of which, after a while, they would take little notice, but a large one attracts too much attention and makes their actions rather unnatural. 14

One wonders what Baldwin Spencer might have been able to achieve if he had had our modern synchronous light-weight cameras and recorders.

10 In 1966 I made a 34 minute edited version of the Baldwin Spencer material under the title Aborigines of Central and Northern Australia 1901, 1912, for a Retrospective of Australian Ethnographic Film at the 1967 Festival dei Popoli in Florence. This film is not generally available. Rights to the Baldwin Spencer material reside with the National Museum of Victoria, Melbourne. 11 Spencer 1928:I, 374.

12 Much of Baldwin Spencer's footage is of secret/sacred ceremonies and should notbe screened publicly. The same applies to other films containing secret/sacred material mentioned here. Extent of restriction is indicated in the filmography appended to this paper.

13 Mourning for Mangatopi by Curtis Levy, 1974, and Goodbye old man by David McDougall, 1977, both for the Australian Institute of Aboriginal Studies.

14 Spencer 1928:II, 900 . 
In 1917 William J. Jackson filmed a number of scenes of Aboriginal life on the North-West Scientific and Exploration Expedition to the West Kimberley. Attempts to locate the film footage have not been successful, although documentation relating to the film is held in the Battye Library, Perth. ${ }^{15}$ In 1922 Dr Brooke Nicholls, a Melbourne dental scientist, filmed people belonging to the Wonkonguru ${ }^{16}$ (now spelled Wangganuru) tribe living in north-eastern South Australia or possibly south-west Queensland. One print of his material was located in 1966 in the Mitchell Library, Sydney. So far as is known it was the only print in existence. A negative has now been made from this. The print consisted of four 3-minute edited films. They belonged to a series of films entitled Native Australia, apparently distributed by Kodak (Australasia) Pty Ltd. The four films are individually called Australian Aborigines: Corroborees; Women at work and play; Implements and weapons; and Arts and crafts. With the films went printed notes prepared by Brooke Nicholls 'the well-known travel-lecturer and naturalist [who] has spent many years in the study of the native tribes and wild life of Australia'.17 The films, and their accompanying notes, were obviously designed for a popular audience.

Brooke Nicholls gets considerably closer to his subjects with his camera than did Baldwin Spencer but I have the feeling that, unlike Baldwin Spencer, he viewed his subjects as objects of curiosity rather than as human beings to be respected. Many of the written titles that are inserted between sequences, for which he was presumably responsible, are at best fanciful and at worst objectionable; for example a shot of a man digging for roots is preceded by "The Australian Aborigines are the nearest living relatives of the extinct anthropoid ape-like man'. Nevertheless Brooke Nicholls has given us a valuable film record from an area not filmed before, or possibly since, by ethnographic film-makers. His films cover a variety of scenes, albeit all rather short, including ritual, food gathering and preparation by men and women, games, making of.artefacts, and armed combat between two men.

One of the most important contributions to Australian ethnographic filmmaking came during the 1930 s. Between 1930 and 1937 the Board for Anthropological Research of the University of Adelaide, in close co-operation with the South Australian Museum, carried out a series of anthropological expeditions mainly in Central Australia. During these expeditions a remarkable collection of film records was made with a total running time of over ten hours.

The country where most of these films were made, the Western Desert of Central Australia, was then largely unexplored by white Australians and many hundreds of Aborigines still lived a completely traditional nomadic life there. It was a country far off the beaten track, where camels were a much surer means of transport than the motor trucks of the day.

None of the men involved in making these films was a professional film-maker and indeed few of them were trained anthropologists. Most were scientists and academics from other disciplines who were intensely interested in Australian Aboriginal culture and who realised the value of film for ethnographic recording. Norman B. Tindale was Curator of Anthropology at the South Australian Museum, Dr T.D. Campbell was a dental scientist at the University of Adelaide, O.E. Stocker was a Sydney businessman and a keen and talented amateur cinematographer, and Dr H.K. Fry (Dip. Anthrop., Oxford, 1912) was a medical practitioner in Adelaide. With little money and a minimum of film stock and equipment this band of enthusiasts produced

15 Robinson 1977.

16 Nicholls, Native Australia and unpublished MS.

17 Nicholls, Native Australia. 
one of the most significant contributions to ethnographic film-making in Australia: Macdonald Downs expedition 1930, Cockatoo Creek expedition 1931, Mt Liebig expedition 1932, Mann Range expedition 1933, Ernabella expedition 1933, Diamantina expedition 1934, Warburton Range expedition 1935, Coorong expedition 1937.

They filmed a great range of activities in remarkable detail: daily life, food collecting and preparation, making of artefacts, studies in body movement and a great deal of sacred ceremonial life. They used a mobile camera and a full range of shots from long shot to extreme close up. Much of their film work is sensitive and of high quality. It reveals, with an extraordinary feeling of immediacy and veracity, the beauty and excitement of desert life.

In 1940 Charles P. Mountford, who was Honorary Associate in Ethnology at the South Australian Museum, made an expedition by camel south-west of Alice Springs into the country around Ayers Rock in Central Australia Here he met a group of desert Aborigines with whom he carried out anthropological research.

He took a movie camera with him and with little knowledge of film-making he shot what was to become one of the most popular films ever made in Australia. It was called Walkabout (originally titled Brown men and red sand). It was in colour, and was, as far as I know, the first Australian ethnographic film to have a sound track added to it at the editing stage. The film was edited and narrated by Mountford. Its style is that of a personal travelogue, with plenty of scenes of the expedition and the country around the spectacular and gigantic monolith Ayers Rock. But the film also contains much detailed ethnographic material on the lives of the Aborigines of the area.

In 1942 Mountford returned to Central Australia for further anthropological research and filming. From this expedition he made Tjurunga, again in colour and with his own narration. This also has had immense popular success. In 1974, at the request of people living in the areas of filming, certain sequences of sacred/secret life were removed from Walkabout and Tjurunga and the two films were combined into one under the title Walkabout (1974 version). This re-editing was carried out by Film Australia which had inherited the safekeeping and distribution of these films from the old Department of Information. In 1948 Mountford accompanied a scientific expedition to Arnhem Land in Northern Australia and shot material which was made into Aborigines of the sea coast and Arnhem Land.

In 1947 the first ethnographic film on Australian Aborigines to be produced by professional film-makers was shot in Northern Australia. It was called Primitive people - the Australian Aborigines. The production company was Gaumont British Instruc: tional Films but the location unit was entirely Australian. The director cameraman was veteran cinematographer George Heath; his assistant and the film's narrator was the then young Peter Finch. The film was shot around Arnhem Bay in north east Arnhem Land, and shows traditional life in the bush. By 1947 many of the people in the film were, in fact, living for at least some of their time at Yirrkala and other isolated church mission stations in the area.

The film is in three parts: The nomads, The hunt and The corroboree. The first part shows excellent scenes of daily life. The second part covers preparations for a wallaby hunt and the hunt itself. This is somewhat marred by intercutting between the hunters in Arnhem Land and their supposed prey in country that looks suspiciously like south-eastern Australia. The corroboree contains some important scenes of mortuary rites, but this is marred by a sound track of unidentified but apparently Aboriginal music that is certainly not from north-east Arnhem Land. It is matched with the image so as to suggest that it is a synchronous recording. The commentary throughout the three parts attempts to be sympathetic but is inaccurate in places and somewhat patronising. However the fine black and white visuals provide us with a valuable record. 
In 1949 A.P. Elkin, Professor of Anthropology at Sydney University from 1934 until 1956, made a film on the Maraian ceremony of south-west Arnhem Land. This was the first serious attempt to record a whole ceremony on film. It was also the first attempt to record a synchronous sound track of ceremonial music and singing. Synchronous sound equipment, in which sound recorder and camera are mechanically or electronically locked together, was not developed for $16 \mathrm{~mm}$ portable cameras until many years after this. So, although Elkin's sound was recorded simultaneously, it could not be laid exactly in sync in the finished film because sound recorder and camera each ran at its own variable speed. Due to the vagaries of the wire recorders of the day and the short duration film magazines, the film is technically variable, but the importance and rarity of the record make it a valuable document.

In 1950 and subsequent years, T.G.H. Strehlow filmed over nine hundred ritual acts in Central Australia, mainly among Aranda and Loritja speaking people. Three films have been made from a small part of this footage: The kangaroo ceremonies linking Ajaii and Malupiti, The honey ant ceremonies of Ljaba and The native cat ceremonies of Watarka. The films are in colour with correct, but not synchronously recorded, natural sound. The films were edited under Strehlow's supervision by the Commonwealth Film Unit. Each film has an important commentary. Strehlow was born on Hermannsburg Mission in Central Australia and grew up speaking Aranda fluently. Because of his linguistic knowledge and his long association with the Aranda he had been able to give a rich interpretation of the songs and dances portrayed in the films. It is tragic that the remainder of Strehlow's footage could not have been fully documented, annotated and edited before his sudden death in 1978 .

In 1951 the Board for Anthropological Research at the University of Adelaide re-commenced its film production programme. Over the next fourteen years Dr T.D. Campbell made nine colour films ${ }^{18}$ with the support of the Board and the voluntary help of his university colleagues. They were all made with Walbiri men and women of Central Australia who were living at Yuendumu Aboriginal settlement. Most of the films deal with Walbiri technology. They show this with detail and clarity.

One of these films, Palya, shows the manufacture of gum from the resin of the spinifex grass of Central Australia Spinifex gum has many uses, some, but not all, of which are shown in this film - in $1901 \mathrm{Baldwin}$ Spencer used it to mend his wooden camera which was cracking in the heat of Central Australia. ${ }^{19}$

Since its formation in 1961 the Australian Institute of Aboriginal Studies has been actively engaged in ethnographic film production, $f$ irst by sponsoring productions and then by producing films with its own film unit. Its first production in 1962 was a co-production with the Australian Commonwealth Film Unit recording a series of dances at Aurukun Mission on Cape York. From this two films Dances at A urukun and Five Aboriginal dances from Cape York were made. Because the sound could not be recorded with synchronous equipment the cutting of the films is determined by the need to keep sound and image as closely in sync as possible. This inevitably mars these two films.

Starting in 1963 four major ceremonial films were made for the Institute by independent film-maker Cecil Holmes. Cecil Holmes was one of the real battlers of the Australian film industry. His active film days were in the fifties and sixties when there was no Australia Council and no Australian Film Commission to give grants and blessings to would-be feature film-makers. His four films for the Institute are all

18 Minjena's lost ground (1951), So they did eat (1953), The boomerang (1958), The woomera (1958), Naburula (1958), Aboriginal axes (1965), Palya (1965), Aboriginal spears (1965), Aboriginal hair string (1965).

19 Spencer 1928:I, 374. 


\section{ETHNOGRAPHIC FILM-MAKING}

comprehensive records of complex Arnhem Land ceremonies: Djalambu (1963), Ubar (1964), Yabuduruwa (1965) and Lorrkun (1966). These films, which vary in length from fifty-five minutes to over two and a half hours, are by far the most detailed film records made up to that time of Aboriginal ritual life in Arnhem Land. The participants in the films were all living on mission stations but they maintained a strong commitment to their traditional religion and its sacred ceremonies. The films are all in colour. The first, Djalambu, has correct but not synchronous sound. The other three have fully synchronous sound. They are the first ethnographic films in Australia to be recorded with synchronous sound equipment. They portray well the richness and complexity of Aboriginal ceremonial life.

I myself first went into Central Australia, to the Western Desert, in 1957 to make a film on a very remote weather station. Several nomadic family groups were camped not far from the weather station and I spent as much time with them as I could. On my return to the Commonwealth Film Unit I proposed a film on the daily life of a nomadic family. Eight years later my proposal was accepted, jointly by the Commonwealth Film Unit and the Australian Institute of Aboriginal Studies which was to sponsor the production. The only trouble was that in the intervening eight years the desert had become practically devoid of people. When I set out in 1965 with Bob Tonkinson, then a young anthropology graduate from Western Australia, and Richard Tucker, a brilliant cameraman, there were as far as I knew possibly three or four family groups living somewhere in the heart of the desert, somewhere in an area about the size of England, Scotland and Wales put together. We were fortunate enough to meet Djagamarra and his family.

From our filming with Djagamarra and his family and other family groups on this and a subsequent trip to the Western Desert in 1967 I made a series of nineteen archival films called People of the Australian Western Desert and a more general film, Desert people. These films deal almost entirely with nomadic family life, hunting and gathering and technology. One family we filmed had been living at Warburton Mission for nine months. We took them back to their own country for filming. The other families we met in the desert. The films are black and white (originally shot in $35 \mathrm{~mm}$ ) with no sound except commentary. They are the last extensive film record of people living a traditional nomadic life in Australia.

In 1966 ethnographic film-making in Australia came of age, as it were, when the first 'Unesco round table on ethnographic film-making in the Pacific area' was held in Sydney. It was at this meeting, attended by a number of distinguished overseas ethnographic film-makers and academics, including Jean Rouch, Robert Gardner and Colin Young, that the outside world and also we ourselves here in Australia discovered that Australia had a remarkably rich history of ethnographic film-making. I think that meeting did much to ensure continued government support for ethnographic filmmaking in this country.

In the year prior to this, in 1965, the Australian Institute of Aboriginal Studies formed its own one-man film unit with Roger Sandall as its producer-directorcameraman. Sandall was a graduate in anthropology from New Zealand, and had studied film production in the U.S.A. In his first three years as film-maker of the Institute he shot and produced films of six major ceremonies in Central and Northern Australia: Walbiri ritual at Ngama (1966), Djunguan of Yirrkala (1966), Emu ritual at Ruguri (1967-68), Mulga seed ceremony (1967), Gunabibi: an Aboriginal fertility cult (1966), Walbiri ritual at Gunadjari (1967).20 All of these were shot in $16 \mathrm{~mm}$ colour

20 After 1968 Roger Sandall made several more ethnographic films before leaving the Australian Institute of Aboriginal Studies in 1972. 
with 100 per cent synchronous sound. Nicolas Peterson was anthropological adviser for all of these productions. The participants were all living on Government settlements or mission stations, but the filming often took place far from these settlements at important sites in the participants' own country.

All Sandall's ceremonial films are made with unobtrusive professionalism. They are characterised by a commitment on his part to record whole events, both spatially and temporally. Outside a small band of academics, this extraordinarily rich body of early work by Roger Sandall has remained virtually unknown in Australia because all the films are records of secret ceremonies and cannot be shown publicly. I attended a very private screening of one of Sandall's films in 1976 at Yirkala in north-east Arnhem Land, where the film was shot. The film was of the Djunguan ceremony in 1966. Besides myself the audience consisted of five or six clan leaders who had been involved in the ceremony - but in fact they were not an audience, they were still participants. As the film started they asked me to turn down the sound and then, with tears rolling down their cheeks, they sang and gently clapped as they relived the ceremony. It was one of the most moving scenes I have ever witnessed.

The first seventy years of ethnographic film-making in Australia marks, more or less, the end of an era. During this period the subject matter of ethnographic film was predominantly that of traditional Aboriginal life. Today's films are about societies in change. During this first seventy years, while the relationship between the film-makers and the people they filmed was mainly one of mutual trust and respect, it was unmistakably the film-maker who guided the course of the film. Today there is a change of emphasis, a much closer co-operation in the film-making process itself between the film-maker and the people being filmed. The film-maker is now often invited by a particular community to make a film, and once there he is then guided by that community. The interaction between film-maker and subject becomes part of the film. With the advent of synchronous sound shooting and translation of dialogue a whole new, intimate and human dimension is being added to ethnographic film. With continued government $\mid$ funding of ethnographic film programmes and with the emergence of a number of new and talented film-makers over the last ten years ethnographic film-making in Australia looks as if it will be as productive in the future as it has been in the past.

FILM AUSTRALLA, LINDFIELD N.S.W.

\section{BIBLIOGRAPHY}

De Brigard, Emilie. 'The history of ethnographic film', in Hockings, Paul ed. Principles of visual anthropology. The Hague, 1975:13-43.

Gillen, F.J. Gillen's diary: the camp jottings of F.J. Gillen on the Spencer and Gillen Expedition across Australia 1901-02. Adelaide, 1968.

Haddon, A.C. Letter to Baldwin Spencer, 1900. Spencer Papers, Pitt-Rivers Museum, Oxford,M.S.

Moyle, Alice M. 'Sir Baldwin Spencer's recordings of Australian Aboriginal singing', National Museum of Victoria, Memoirs, (24), 1959:7-36.

Nicholls, Brooke. Unpublished MS, n.d. Mitchell Library, Sydney. Native Australia, (notes on films), nd. Mitchell Library, Sydney,

Robinson, Michael V. 'The Jackson film of 1917', Australian Institute of Aboriginal Studies, Newsletter, n.s. (6), 1976:17-20.

Spencer, Sir Baldwin. Wanderings in wild Australia. London, 1928. 


\section{ETHNOGRAPHIC FILM-MAKING}

\section{FILMOGRAPHY}

Films are listed in order of discussion in this paper. The information given here is:

a. Classification by secret/sacred content: * indicates that some parts or reels are restricted;

** indicates that all or most is restricted.

b. Title (or descriptive title if unfinished production).

c. Year of shooting (if known, rather than year of completion).

d. Source for further inquiries.

e. Source of print in Australia shown in brackets if this is different from (d).

The National Library, Canberra, holds prints of many of these films.

Hoddon Film, 1898, University Museum of Archaeology and Ethnology, Cambridge, (Australian Institute of Aboriginal Studies, Canberra).

** Baldwin Spencer Film, 1901, 1912, National Museum of Victoria, Melbourne.

** Aborigines of Central and Northern A ustralia, 1901, 1912, Film Australia, Lindfield, N.S.W. Native Australio, 1922, (i) Australian Aborigines - comoborees, (ii) Australian Aborigines women at work and play, (ii) Australian Aborigines - implements and weapons, (iv) Australian Aborigines - arts and crafts, Mitchell Library, Sydney, (Film Australia, Lindfield, N.S.W.).

* Macdonald Downs expedition, 1930, Board for Anthropological Research, University of Adelaide.

* Cockatoo

Adelaide.

* Mt Liebig expedition, 1932, Board for Anthropological Research, University of Adelaide.

* Mann Range expedition, 1933, Board for Anthropological Research, University of Adelaide.

* Ernabella expedition, 1934, Board for Anthropological Research, University of Adelaide.

* Diamantina expedition, 1934, Board for Anthropological Research, University of Adelaide.

* Warburton Range expedition, 1935, Board for Anthropological Research, University of Adelaide.

Coorong expedition, 1937, Board for Anthropological Research, University of Adelaide.

* Walkabout, 1940, Film Australia, Lindfield, N.S.W.

** Tjurunga, 1942, Film Australia, Lindield, N.S.W.

Walkabout (1974 Version) 1940, 1942, Film Australia, Lindfield, N.S.W.

Aborigines of the sea coast, 1948, Film Australia, Lindfield, N.S.W.

Arnhem Land, 1948, Film Australia, Lindfield, N.S.W.

Primitive people - the Australian Aborigines, 1947, Rank Film Library, Greenford, Middlesex, (National Library, Canberra).

** Maraion, 1949, University of Sydney.

** The kangaroo ceremonies linking Ajaii and Malupiti, 1950, Film Australia, Lindfield, N.S.W.

** The honey ant ceremonies of Ljaba, 1950, Film Australia, Lindfield, N.S.W.

** The native cat ceremonies of Watarka, 1950, Film Australia, Lindfield, N.S.W.

Minjena's lost ground, 1951 , Board for Anthropological Research, University of Adelaide. So they did eat, 1953, Board for Anthropological Research, University of Adelaide.

The boomerang, 1958, Board for Anthropological Re search, University of Adelaide.

The woomera, 1958, Board for Anthropological Research, University of Adelaide.

Nabarula, 1958, Board for Anthropological Research, University of Adelaide.

Aboriginal axes, 1965, Board for Anthropological Research, University of Adelaide.

Palya, 1965, Board for Anthropological Research, University of Adelaide.

Aboriginal spears, 1965, Board for Anthropological Research, University of Adelaide.

Aboriginal hair string, 1965, Board for Anthropological Research, University of Adelaide.

Dances at Aurukun, 1962, Film Australia, Lindfield, N.S.W.

Five Aboriginal dances from Cape York, 1962, Film Australia, Lindfield, N.S.W.

Djalambu, 1963, Australian Institute of Aboriginal Studies, Canberra.

** Ubar, 1964, Australian Institute of Aboriginal Studies, Canberra.

** Yabuduruwa, 1965, Australian Institute of Aboriginal Studies, Canberra.

** Lorkun, 1966, Australian Institute of Aboriginal Studies, Canberra.

People of the Australian Western Desert, parts I-10, 1965, Film Australia, Lindfield, N.S.W. (*Part 3 only).

Desert people, 1965, Film Australia, Lindfield, N.S.W.

People of the Australian Western Desert, parts $11-19,1967$, Film Australia, Lindfield, N.S.W. (*Parts 11 and 17 only).

** Walbiri ritual at Ngama, 1966, Australian Institute of Aboriginal Studies, Canberra.

** Djunguan of Yirrkala, 1966, Australian Institute of Aboriginal Studies, Canberra.

** Emu ritual at Ruguri, 1967-8, Australian Institute of Aboriginal Studies, Canberra.

** Mulga seed ceremony, 1967, Australian Institute of Aboriginal Studies, Canberra.

** Gunabibi: an Aboriginal fertility cult, 1966, Australian Institute of Aboriginal Studies, Canberra.

** Walbiri ritual at Gunadjari, 1967, Australian Institute of Aboriginal Studies, Canberra. 